\title{
FURNITURE CONSTRUCTION SKILL GAP ANALYSIS AMONG TECHNICAL COLLEGE TEACHERS IN ZAMFARA AND KATSINA STATES
}

\author{
${ }^{1}$ Mannir, M.S, ${ }^{2}$ Bala, M.M., and ${ }^{3}$ Hassan, A.M. \\ ${ }^{1}$ Department of Primary Education, Federal College of Education Technical (Female), Gusau, Nigeria \\ ${ }^{2,3}$ Department of Industrial and Technology Education, Federal University of Technology, Minna, Nigeria \\ E-mail: yabhass@yahoo.com
}

\begin{abstract}
This study identified the practical skills possessed and skills required by furniture construction teachers in Zamfara and Katsina State, Nigeria. Three research questions that sort to determine the skills needs of furniture construction teachers were answered and one hypothesis was tested at 0.05 level of significance. A descriptive survey research design was adopted for the study. The population for the study was 42 teachers. A structured questionnaire was used to gather data from the 42 woodwork furniture construction teachers. The instrument had a reliability coefficient of 0.89 using Cronbach Alpa statistic. Mean and standard deviation was used to answer research questions and a t-test was used to test the hypothesis using the IBM SPSS version 20. The findings of the study revealed that the respondents require skills on the ability to hold a saw with fore-finger straight out on one side of the handle, the ability to follow the "FEWTEL" method in preparing a piece of wood require further training, setting sliding bevel when marking out dovetail joint and selection of the right adhesive according to the purpose and type of wood as well as amount of force the adhesive would be subjected to required skills. It was recommended that; government should provide opportunities for furniture construction teachers to go on further training on the modern furniture construction technology required. The identified skills required by teachers of furniture construction should form the basis for the up-skill workshop to be organized as in-house training.
\end{abstract}

Keywords: analysis, furniture construction, skill gap, technical colleges

\section{INTRODUCTION}

In Nigeria, technical colleges are considered to be the key vocational institutions set up to train people to learn practical skills, knowledge, and attitudes for successful involvement in the world of work. Hussaini [1] stated that technical colleges give training intended to prepare students for entry into various occupations. The Federal Republic of Nigeria [2] outlined the aim of technical colleges, which include preparation for useful living within the society and higher education. It means that the quality of instruction at technical colleges must in addition to the development of the cognitive or intellectual abilities of the youths be oriented towards the acquisition of appropriate work skills, abilities, and competences for the individuals to live and contribute to the development of the society. The aim of technical education about traderelated courses in technical colleges, however, is unlikely to succeed by using the "chalk and talk" approach alone, except by using educational tools effectively to bring students into contact with the school curriculum and by streamlining learning activities. Emma [3] noted that resources relate to the equipment, people, time, and funds available that can be used to achieve educational objectives and goals. Orebanjo \& Hirschheim [4] also stated that good human resources, especially well-trained, qualified and committed teachers, assist students in various aspects of practical project creation and acquisition of skills in services related to woodwork. The need to 
shift from mere acquisition of knowledge through the operation and construction of furniture craft machines and studying performance characteristics of furniture craft technology teachers' technical colleges. For example, graduates of a technical institution who are prepared to teach in technical colleges must be well, effectively, and sophisticatedly trained to learn relevant skills to manage modern furniture equipment under complexities in modern machines. Hence, for the technical college graduates to be well qualified in furniture craft technology, their teachers must have had the necessary skills available to teach the subject at the college level. Ede \& Yusuf [5] stated that, for students to effectively carry out frame construction, carcass, and construction, and stool construction, they need the skills to make use of tools and equipment. Graduates of technical colleges require appropriate skills to be employable or self-reliant in Furniture Craft.

The skill gap in most Nigerian furniture craft graduates is subject to a series of retraining programs because most of them are considered to be ill-equipped and adjudicated to be unemployed based on the standard of the training they have acquired [6], [7]. In situations where our indigenous furniture craft graduates cannot be hired and retrained by industries, they theoretically carry the 'expatriates' to do the same work. Over time, Nigerians have struggled to resolve the skill gaps that exist and reduce the utility of furniture design graduates from Nigerian educational institutions through the cooperation of furniture design institutions and industries for training programs. Accordingly, for furniture craft in Nigeria to achieve its intended goals, it needs to be properly reinforced by cooperation in school-workplace training. The Furniture Craft program in Technical Colleges in
Zamfara and Katsina State has not provided the necessary skills in practice as expected from Furniture Craft students [8]. The information obtained from the Board of Executive Secretaries, Science and Technical Schools, Ministry of Education, States of Zamfara and Katsina, showed that Furniture Craft students have been poorly performing in woodworking technology trades, especially in practical ones, for the past five years. This may be due to the lack of improved skills in carrying out practical work by the Furniture Craft teachers. The furniture construction skills difference between technical college teachers in Zamfara and Katsina State of Nigeria was established in this study. The study explicitly identifies: (1) the skills deficit of furniture craft teachers in technical colleges, (2) the skills of furniture craft teachers in technical colleges in furniture design, (3) the skills needs of furniture craft teachers in technical colleges.

Technical teachers are human resources who have earned specialized instruction in trade theory and practice and pedagogy. In this regard, professional teachers are referred to those who have earned technical training in knowledge, skills, and attitudes relevant to the theories and practice of education to develop aspects of practical issues and to minimize unemployment problems in society [9]. Successful vocational systems have to focus mainly on teacher training [10].

Numerous problems are facing the performance of technical college graduates in terms of practical furniture construction in the state of Zamfara and Katsina, such as lack of improved practical skills from furniture craft teachers, inadequate teaching methods for furniture construction, acute lack of trained furniture craft teachers, lack of facilities as well as insufficient funding 
[11]. In addition, the issues led to the low performance of college students in the design of furniture, which needs to be changed. Therefore, it is noteworthy that enhanced skills of furniture craft teachers will make a significant contribution to the efficient output of practical furniture craft students in technical colleges in Zamfara and Katsina State. Therefore, this requires means or ways to develop a gap analysis of Furniture Construction skills among technical college teachers in Zamfara and Katsina state. Technical colleges are producing craftsmen who constitute a lower level of manpower required by the furniture industry. Technical college graduates must have acquired the essential skills in the field for self-reliance or gainful jobs. Most technical college graduates in Nigeria, however, are neither self-reliant as entrepreneurs nor readily employed by industries. This may probably be due to the lack of suitable skills available for jobs. The performance of the students in NTC assessments in Zamfara and Katsina States during the last five years indicates low results. The NABTEB 's Chief Examiner attributed the low performance of students to furniture craft teachers' lack of skills in furniture construction. The shortage of sufficient teaching and furniture building skills for teachers must be decided to provide a solution by supplying qualified labor to churn out unskilled technical college graduates. Furniture markets are not saturated, but since technical college graduates lack practical skills that can be sold, they shy away from employment that would require those skills. This situation is of concern because millions of young people are on the street wandering without the skills required for profitable jobs. Therefore, this study necessitates the need to recognize the skills needed by Furniture Craft teachers in technical colleges to effectively teach furniture construction and keep up with modern Nigeria's changing work environments.

The following questions were answered to achieve the stated objectives for the study: (1) What are the construction skills needed by furniture craft teachers? (2) What are the construction abilities that furniture craft teachers possess? (3) What are the criteria for the skills gap for furniture craft teachers at technical colleges? At the 0.05 level of significance, the null hypothesis was formulated and evaluated. There is no significant difference between the mean scores of low and highly experienced teachers on the skills needed by furniture craft teachers on furniture construction at Zamfara and Katsina state technical colleges.

\section{METHOD}

For the study, a descriptive survey research design was adopted. The research was carried out at technical colleges in the states of Zamfara and Katsina. The population for this study consists of all 47 teachers of furniture craft technology in Government Technical College, Kaura, Government Technical College, Gusau, Government Technical College, Mafara, Government Technical College, Bakura in Zamfara State and Govt. Girls' Tech. Commercial College, Charanchi, Government Technical College, Funtua, Government Technical College, Ingawa, and Government Technical College, Mashi in Katsina State. The data were gathered from the Ministry of Education of the State of Zamfara and Katsina. Since the population is manageable, the survey included all the population, so there was no sampling. A standardized questionnaire developed by the 
researchers was the instrument for data collection. Under the research questions established to direct the analysis, the items in the questionnaire were arranged. Three lecturers in the Ministry of Industrial and Technology Education, Federal University of Technology, Minna validated the instrument. For clarification of content and relevance to the analysis, the instrument was validated. Validates were requested to include feedback for enhancing the instrument to serve the purpose of the report. The suggested corrections were affected and inserted into the updated copy of the instrument used to gather data.

The researchers have adopted a statistical method by Cronbach Alpa to determine the instrument's internal consistency. The instrument was administered to teachers of woodworking technology at Minna Government Technical College. The respondents were administered eight copies of the validated instrument. The same instrument was also administered to the same respondents after two weeks. In evaluating the reliability of the instrument at 0.89, Pearson's Product Moment Correlation Coefficient was used. At Minna government technical college, which is outside the field of research, the instrument was tested. Researchers administered the instrument on the respondents with the assistance of two (2) research assistants (one in Zamfara and one in Katsina Province, respectively). The research assistants were instructed by researchers on how the instrument should be administered. The instrument was administered to respondents by the researcher and the research assistants and the instrument was collected immediately after completion. The data collected were analyzed using Mean and Standard Deviation to answer research questions using the t-test to determine the gap in capacity. Using IBM SPSS Statistics version 20 , t-test analysis was used to test the null hypothesis at the 0.05 level of significance. In the t-test table, the acceptance or rejection of the null hypothesis was based on the result of the significance value.

\section{RESULTS AND DISCUSSION}

The skills required in furniture construction by furniture craft teachers in technical colleges: 42 skills are required and 23 skills are not required. They are presented in Table 1. Table 1 showed that the mean of items of the respondents agreed with items 1 to 4 in hand sawing skills, indicating that they require skills in those stated. Items 9 and 10 on adjustment of blade to correct level of cutting edge and ability to follow the 'FEWTEL' method in preparing a piece of wood were required. The respondents also demand training on items 16 to 21 which are for the preparation of tools and using machine tools. At the same time skills in wood joints making also, require training in all the items. The respondents' view on skills in gluing and assembling of work shows that the respondents require skills in all the items except item 34 which is on selection and use of correct cramps. The respondents indicate that they require skills in the preparation of wood using machine tools in items. Skills in wood joints making require skills in items 22 to 24 , and 26 to 28 .

The respondent's opinion on skills in gluing and assembling of work indicates that they require skills in all the items except item 34 which is selection and use of correct cramps. Wood finishing skills result from respondents show that they require skills in items 41 to 42 , and 49 to 51 . At the same time respondents require maintenance skills in items 53 to 55,58 to 59 , and 64 to 65 this is because the mean ranges from 3.29 and 
4.14. The standard deviation values of the items in Table 4.1 range from 0.84 to 1.53 , this implies that the respondents were closer to each other in their responses to the items. This is an indication that the respondents have a similar opinion on the skills required. The skills possessed in furniture construction by furniture craft teachers in technical colleges: 25 skills are possessed and 40 skills are not possessed (Table 2).

Table 1. Mean with Standard Deviation of Respondents on the Skills Required in Furniture Construction by Furniture Craft Teachers in Technical Colleges

\begin{tabular}{|c|c|c|c|c|}
\hline $\mathrm{S} / \mathrm{N}$ & Items & Mean & SD & Remarks \\
\hline \multicolumn{5}{|c|}{ Skills in Hand sawing } \\
\hline 1 & Observe tools for safety precautions. & 3.81 & 0.97 & RQ \\
\hline 2 & Select the right saw for a particular type of sawing. & 3.21 & 0.90 & RO \\
\hline 3 & Measure and mark the outline. & 4.02 & 0.98 & RO \\
\hline 4 & Use the right holding device before sawing. & 3.86 & 0.98 & RQ \\
\hline 5 & Hold the saw with the forefinger straight out on one side of the handle. & 2.50 & 0.97 & NRQ \\
\hline 6 & Guide the initial strokes using the thumb and maintain a proper sawing angle. & 2.81 & 1.02 & NRQ \\
\hline 7 & Apply moderate pressure while sawing. & 2.93 & 0.97 & NRQ \\
\hline \multicolumn{5}{|c|}{ Skills in hand planning } \\
\hline 8 & Select the right plane for a particular operation. & 2.88 & 0.94 & NRQ \\
\hline 9 & Adjust the blade to the correct level of cutting edge. & 4.19 & 0.94 & RQ \\
\hline 10 & Follow the 'FEWTEL' method in preparing a piece of wood. & 3.76 & 1.16 & RQ \\
\hline \multicolumn{5}{|c|}{ Preparation of wood using a machine tool } \\
\hline 11 & Observe machine safety precautions. & 2.95 & 0.94 & NRQ \\
\hline 12 & Use a surface planer to plane the face-side. & 2.64 & 1.03 & NRQ \\
\hline 13 & Use a jointer to plane the face-edge. & 4.17 & 1.01 & RQ \\
\hline 14 & Adjust circular saw fence to the required width. & 2.55 & 1.13 & NRQ \\
\hline 15 & Feed the stock slowly and evenly to rip to the width. & 3.88 & 1.02 & RQ \\
\hline 16 & Use a thickening machine and plane to the required thickness. & 4.24 & 0.79 & RQ \\
\hline 17 & Use a cross-cutting saw machine to cut one end square to the face side. & 4.14 & 0.87 & RQ \\
\hline 18 & Measure and set the length of cut on cross-cutting saw machine. & 4.00 & 1.06 & RQ \\
\hline 19 & $\begin{array}{l}\text { Hold the stock on the cross-cutting saw machine table and guide the blade to cut } \\
\text { to the length. }\end{array}$ & 4.31 & 0.98 & RQ \\
\hline 20 & Use a woodturning lathe for spindle turning. & 4.07 & 0.95 & RQ \\
\hline 21 & Use a woodturning lathe for faceplate turning. & 3.86 & 1.05 & RQ \\
\hline \multicolumn{5}{|c|}{ Skills in wood joints making } \\
\hline 22 & Interpret working drawings. & 4.07 & 1.00 & RQ \\
\hline 23 & Mark-out joints to specifications. & 4.19 & 0.92 & RQ \\
\hline 24 & Set sliding bevel when marking out the dovetail joint. & 4.05 & 1.13 & RQ \\
\hline 25 & Use backsaws in cutting out waste. & 2.33 & 1.03 & NRQ \\
\hline 26 & Use a chisel and mallet with the correct force to remove waste. & 3.52 & 1.21 & RQ \\
\hline 27 & Label a couple of joints. & 3.45 & 1.35 & RQ \\
\hline 28 & Trial assembles a project. & 3.38 & 1.06 & RQ \\
\hline \multicolumn{5}{|c|}{ Skills in gluing and assembling of work } \\
\hline 29 & Select the right adhesive according to the purpose and type of wood. & 3.76 & 1.28 & RQ \\
\hline 30 & Mix adhesives to the required viscosity. & 3.71 & 1.11 & RQ \\
\hline 31 & Consider the amount of force the adhesive would be subjected to. & 3.69 & 1.22 & RQ \\
\hline 32 & Understand the glue pot life, open time, closed time, and clamping time. & 3.67 & 1.16 & RQ \\
\hline 33 & Apply sufficient adhesive on surfaces to be bonded. & 3.71 & 1.20 & RQ \\
\hline 34 & Select and use the correct cramps. & 2.98 & 0.90 & NRQ \\
\hline 35 & Sub-assemble large projects. & 3.38 & 1.23 & RQ \\
\hline 36 & Remove excess adhesive using soft, clean, and wet cloth. & 3.12 & 1.27 & RQ \\
\hline 37 & Test the squareness of the work before final cramping. & 3.62 & 1.19 & RQ \\
\hline 38 & Assemble a job using screws and nails. & 3.62 & 1.08 & RQ \\
\hline 39 & Use a pneumatic screwdriver. & 3.10 & 1.05 & RQ \\
\hline \multirow{2}{*}{\multicolumn{5}{|c|}{ Wood finishing skills }} \\
\hline & & & & \\
\hline 41 & Use scraper/sandpaper in removing dry adhesive from the surfaces. & 3.48 & 1.53 & RQ \\
\hline 42 & Raise dent with hot water and sponge. & 3.21 & 1.12 & RQ \\
\hline 43 & Remove grease and oils from the surface before applying finishes. & 2.57 & 0.99 & NRQ \\
\hline
\end{tabular}




\begin{tabular}{clccc}
\hline S/N & \multicolumn{1}{c}{ Items } & Mean & SD & Remarks \\
\hline 44 & Wood filler to patch nail holes, scratches, and cracks with the right material. & 2.45 & 0.89 & NRQ \\
45 & Sand the work with abrasives using proper grades of sanding paper. & 2.76 & 1.03 & NRQ \\
46 & Remove dust by brushing or by using an air blower. & 2.83 & 0.96 & NRQ \\
47 & Apply sanding sealer on surfaces. & 2.69 & 1.05 & NRQ \\
48 & Select and apply the finish with a brush. & 2.55 & 0.89 & NRQ \\
49 & Load and Select ideal air pressure (psi) when spraying. & 3.55 & 1.21 & RQ \\
50 & Use the roller correctly when applying finishes. & 3.64 & 1.16 & RQ \\
51 & Use a brush at an appropriate angle. & 4.40 & 0.77 & RQ \\
& & & & \\
52 & Observe daily or routine maintenance on a machine before use. & 2.83 & 1.03 & NRQ \\
53 & Remove, change, or sharpen circular saw blade. & 3.29 & 1.09 & RQ \\
54 & Oil and grease ball bearings. & 3.98 & 0.84 & RQ \\
55 & Remove and replace planer machine blades. & 4.07 & 1.18 & RQ \\
56 & Oil and grease screws and slides in the planer machine. & 2.95 & 0.99 & NRQ \\
57 & Sharpen band saw blade. & 2.88 & 1.09 & NRQ \\
58 & Repair broken band saw blade. & 4.10 & 1.01 & RQ \\
59 & Sharpen ripsaw teeth. & 4.00 & 0.96 & RQ \\
60 & Sharpen cross-cut saw teeth. & 2.98 & 0.98 & NRQ \\
61 & Sharpen hand plane blades. & 2.50 & 1.25 & NRQ \\
62 & Sharpen planer machine blades. & 2.90 & 1.03 & NRQ \\
63 & Replace or recondition worn-out tools. & 2.55 & 1.09 & NRQ \\
64 & Store tools in the right place. & 4.00 & 1.01 & RQ \\
65 & Clean spray gun & 4.14 & 0.95 & RQ \\
\hline
\end{tabular}

KEY: SD = Standard Deviation, RQ = Require and NRQ = Not Require

Table 2. Mean with Standard Deviations of Respondents on the Skills Possessed in Furniture Construction by Furniture Craft Teachers in Technical Colleges

\begin{tabular}{|c|c|c|c|c|}
\hline $\mathrm{S} / \mathrm{N}$ & Items & Mean & SD & Remark \\
\hline \multicolumn{5}{|c|}{ Skills in Hand sawing } \\
\hline 1 & Observe tools of safety precautions. & 2.98 & 1.30 & NPS \\
\hline 2 & Select the right saw for a particular type of sawing. & 2.81 & 0.94 & NPS \\
\hline 3 & Measure and mark the outline. & 2.76 & 0.96 & NPS \\
\hline 4 & Use the right holding device before sawing. & 2.74 & 1.31 & NPS \\
\hline 5 & Hold the saw with the forefinger straight out on one side of the handle. & 3.07 & 1.05 & POS \\
\hline 6 & Guide the initial strokes using the thumb and maintain a proper sawing angle. & 3.26 & 1.15 & POS \\
\hline 7 & Apply moderate pressure while sawing. & 3.12 & 1.27 & POS \\
\hline & Skills in hand planning & & & \\
\hline 8 & Select the right plane for a particular operation. & 2.67 & 1.03 & NPS \\
\hline 9 & Adjust the blade to the correct level of cutting edge. & 3.00 & 1.21 & POS \\
\hline \multicolumn{5}{|c|}{ Preparation of wood using a machine tool } \\
\hline 11 & Observe machine safety precautions. & 2.93 & 1.22 & NPS \\
\hline 12 & Use a surface planer to plane the face-side. & .83 & 1.08 & NPS \\
\hline 13 & Use a jointer to plane the face-edge. & 3.36 & 1.30 & POS \\
\hline 14 & Adjust circular saw fence to the required width. & 3.19 & 0.99 & POS \\
\hline 15 & Feed the stock slowly and evenly to rip to the width. & 3.05 & 1.03 & POS \\
\hline 16 & Use a thickening machine and plane to the required thickness. & 3.43 & 1.27 & POS \\
\hline 17 & Use a cross-cutting saw machine to cut one end square to the face side. & 2.90 & 0.98 & NPS \\
\hline 18 & Measure and set the length of cut on cross-cutting saw machine. & 2.62 & 1.01 & NPS \\
\hline 19 & $\begin{array}{l}\text { Hold the stock on the cross-cutting saw machine table and guide the blade to cut } \\
\text { to the length. }\end{array}$ & 3.07 & 1.24 & POS \\
\hline 20 & Use a woodturning lathe for spindle turning. & 2.93 & 1.24 & NPS \\
\hline 21 & Use a woodturning lathe for faceplate turning. & 3.00 & 1.25 & POS \\
\hline \multicolumn{5}{|c|}{ Skills in wood joints making } \\
\hline 22 & Interpret working drawings. & 2.48 & 1.06 & NPS \\
\hline 23 & Mark-out joints to specifications. & 2.74 & 1.13 & NPS \\
\hline 24 & Set sliding bevel when marking out the dovetail joint. & 3.07 & 1.28 & POS \\
\hline 25 & Use backsaws in cutting out waste. & 2.81 & 0.94 & NPS \\
\hline
\end{tabular}




\begin{tabular}{|c|c|c|c|c|}
\hline $\mathrm{S} / \mathrm{N}$ & Items & Mean & SD & Remark \\
\hline 26 & Use a chisel and mallet with the correct force to remove waste. & 2.86 & 1.03 & NPS \\
\hline 27 & Label a couple of joints. & 3.02 & 1.05 & POS \\
\hline 28 & Trial assembles a project. & 3.29 & 1.33 & POS \\
\hline $\begin{array}{l}29 \\
30\end{array}$ & $\begin{array}{l}\text { Skills in gluing and assembling of work } \\
\text { Select the right adhesive according to the purpose and type of wood. }\end{array}$ & 2.81 & 1.15 & $\begin{array}{l}\text { NPS } \\
\text { NPS }\end{array}$ \\
\hline 30 & Mix adhesives to the required viscosity. & $\begin{array}{l}2.95 \\
3.17\end{array}$ & $\begin{array}{l}1.08 \\
1.23\end{array}$ & $\begin{array}{l}\text { NPS } \\
\text { POS }\end{array}$ \\
\hline $\begin{array}{l}31 \\
32\end{array}$ & $\begin{array}{l}\text { Consider the amount of force the adhesive would be subjected to. } \\
\text { Understand the glue pot life, open time, closed time, and clamping time. }\end{array}$ & $\begin{array}{l}3.17 \\
3.07\end{array}$ & $\begin{array}{l}1.23 \\
1.13\end{array}$ & $\begin{array}{l}\text { POS } \\
\text { POS }\end{array}$ \\
\hline 33 & Apply sufficient adhesive on surfaces to be bonded. & 2.69 & 1.05 & NPS \\
\hline 34 & Select and use the correct cramps. & 3.00 & 1.25 & POS \\
\hline 35 & Sub-assemble large projects. & 3.10 & 1.14 & POS \\
\hline 36 & Remove excess adhesive using soft, clean, and wet cloth. & 2.98 & 1.09 & NPS \\
\hline 37 & Test the squareness of the work before final cramping. & 2.83 & 0.93 & NPS \\
\hline 38 & Assemble a job using screws and nails. & 2.79 & 1.18 & NPS \\
\hline 39 & Use a pneumatic screwdriver. & 3.17 & 1.19 & POS \\
\hline 40 & Use a pneumatic hammer. & 3.21 & 1.09 & POS \\
\hline \multicolumn{5}{|c|}{ Wood finishing skills } \\
\hline 42 & Raise dent with hot water and sponge. & 2.74 & 1.21 & NPS \\
\hline 43 & Remove grease and oils from the surface before applying finishes. & 2.95 & 1.25 & NPS \\
\hline 44 & Wood filler to patch nail holes, scratches, and cracks with the right material. & 3.24 & 1.34 & POS \\
\hline 45 & Sand the work with abrasives using proper grades of sanding paper. & 3.21 & 1.26 & POS \\
\hline 46 & Remove dust by brushing or by using an air blower. & 2.62 & 1.08 & NPS \\
\hline 47 & Apply sanding sealer on surfaces. & 2.74 & 1.08 & NPS \\
\hline 48 & Select and apply the finish with a brush. & 2.90 & 1.16 & NPS \\
\hline 49 & Load and Select ideal air pressure (psi) when spraying. & 3.40 & 1.06 & POS \\
\hline 50 & Use the roller correctly when applying finishes. & 2.43 & 0.89 & NPS \\
\hline 51 & Use a brush at an appropriate angle. & 2.98 & 1.16 & NPS \\
\hline \multicolumn{5}{|c|}{ Maintenance Skills } \\
\hline 52 & Observe daily or routine maintenance on a machine before use. & 2.71 & 0.97 & NPS \\
\hline 53 & Remove, change, or sharpen circular saw blade. & 3.12 & 1.17 & POS \\
\hline 54 & Oil and grease ball bearings. & 2.93 & 1.11 & NPS \\
\hline 55 & Remove and replace planer machine blades. & 2.64 & 1.06 & NPS \\
\hline 56 & Oil and grease screws and slides in the planer machine. & 3.50 & 1.31 & POS \\
\hline 57 & Sharpen band saw blade. & 2.76 & 1.03 & NPS \\
\hline 58 & Repair broken band saw blade. & 2.64 & 0.93 & NPS \\
\hline 59 & Sharpen ripsaw teeth. & 2.98 & 1.12 & NPS \\
\hline 60 & Sharpen cross-cut saw teeth. & 2.76 & 0.91 & NPS \\
\hline 61 & Sharpen hand plane blades. & 2.90 & 1.12 & NPS \\
\hline 62 & Sharpen planer machine blades. & 2.57 & 0.94 & NPS \\
\hline 63 & Replace or recondition worn-out tools. & 2.76 & 1.14 & NPS \\
\hline 64 & Store tools in the right place. & 2.71 & 0.97 & NPS \\
\hline 65 & Clean spray gun & 2.98 & 1.18 & NPS \\
\hline
\end{tabular}

Table 2 showed that the mean of items of the respondents agreed they do not possess kills in hand sawing with items 1,2 , 3 , and 4 . The respondents also agree that they do not possess skills in hand planning, items 8 (2.67), and 10 (2.52) on adjustment of blade to the correct level of cutting edge and the ability to follow the 'FEWTEL' method in preparing a piece of wood were obvious. The respondents do not possess skills in items $11,12,17$, and 20 , which are for the preparation of tools using machine tools. At the same time, skills in wood joints making also show that the respondents only possess skills items 24, 2527 , and 286 which are the ability to set sliding bevel when marking out dovetail joint, use of backsaws in cutting out waste, and labeling 
couple of joints. The respondents' view on skills in gluing and assembling of work shows that the respondents do not possess skills in items 29, 30, 33, 36, 37 and 38. The respondents' opinion on skills in wood finishing indicates that the respondents do not possess skills in items $46,47,48,50$, and 51. Skills in maintenance indicate that the respondents do not possess skills in items 54,55 , and 57 to 65 this is because the mean ranges from 2.57 to 2.98 . The standard deviation values of the items in Table 2 range from 0.89 to 1.34 , this implies that the respondents were closer to each other in their responses to the items. This is an indication that the respondents have a similar opinion on the skills possessed.
There is also no indication that the teachers possessed those skills by themselves; it may be during their previous study or training. Results in Table 1, also show furniture teachers require 40 skills; while Table 2 shows that furniture craft teachers only possessed 25 of the skills required, which is far inadequate for a sound academic program anywhere. Furniture craft teachers require upskilling in 15 skills to improve their ability in training their students for self-reliance and employability. The Hypothesis is there was no significant difference between the mean responses of low and highly experience furniture craft teachers on the skills required and the skills possessed.

Table 3. T-Test Analysis of the Mean Responses of Low and Highly Experienced Furniture Craft Teachers on the Furniture Construction Skills Possessed

\begin{tabular}{cccccccc}
\hline Skills & $\mathrm{N}$ & Mean & SD & Std. Error Mean & $\mathrm{t}$ & $\mathrm{df}$ & Sig. (2-tailed) \\
\hline $\begin{array}{c}\text { Low experienced } \\
\text { teachers }\end{array}$ & 42 & 3.71 & 2.91 & 2.86 & & & \\
$\begin{array}{c}\text { Highly experience } \\
\text { teachers }\end{array}$ & 42 & 3.12 & 1.81 & 1.92 & 9.579 & 41 & 0.000 \\
\hline
\end{tabular}

The result of the analysis as presented in Table 3 indicates that there was a significant difference in the mean of skill required $(\mathrm{M}=3.71, \mathrm{SD}=2.91)$ and skill possessed $(\mathrm{M}=3.12, \mathrm{SD}=1.81)$ by low experience and highly experience on furniture construction teachers. $\mathrm{t}=9.579, \mathrm{p}$ $=0.000$. The result suggested that there was a wide gap between skill required and the skills possessed by both experienced and low experienced teachers of furniture construction teachers. This could be an indication that both low and highly experience teachers got training during their school days. The experience did not impact the skills of highly experienced teachers.

Findings on the skills in furniture construction required by furniture craft teachers in technical colleges indicated that they cannot hold a saw with the forefinger straight out on one side of the handle and applying moderate pressure while sawing; the same applies to the selection of the right saw for a particular job. This is an indication that teachers of furniture makers lack practical skills inability to apply moderate pressure while sawing and selection of the right saw for a particular job. Ezewu [12] remarked that, in learning a skill, about 65 percent of the time should be spent on practical aspects to obtain functional technology in technical colleges. Ezewu [12] believed that well-equipped furniture craft workshops and functional machines must be provided as this will enable the individual to marry theory with practice. It should be noted that the major purpose of vocational education is not to give certificate only, but 
also to train skill workers, especially workers who can function in their respective place of work [13]. The success of any plan to prepare teachers for furniture craft will largely depend upon the ability of our teachers to be responsive to both the employability skill development needs and prospective employer's skills requirement. The development of skills varies with the nature, complexity, type of activities, and people who opt for such skill development. The ability to have interest, aptitudes, patience, personality and other human or physical qualities will enable them to succeed in skills in furniture construction teachers. It is commonly misconceived that; the development of skill requires low brains. Indeed most skill development activities present great challenges to the learner on the integration of the practical work, theoretical fields, common sense, good power of observation, and courage [14]. For the development of skills, Okoro [15] opined that all technical courses irrespective of their levels and objectives must stress practical activities. Any technical course in which a large proportion of the allocated time is not devoted to a practical activity or work, project or experiment, is not likely to be adequate and become successful.

Findings also revealed that skills in wood preparation using machine tools, in particular taking precautionary measures in the field of protection, require updated skills, particularly the use of joiners to plane the face edge and adjust circular saw fence to the required width. In furniture construction, all these processes are essential operations. This skill gap means that these abilities are missing for both low and highly experienced furniture design teachers and the ability to transfer instruction to their students would be negative. Bukar [16] stated that the practice of furniture craft is an instructional method used by an industrial technology instructor to attain a satisfactory level of acquisition of skills. The consequence of this is that furniture teachers would have to upgrade their abilities to transfer quality instruction to their students effectively.

Findings in the manufacture of wood joints, such as the understanding of working drawing and the use of a chisel, mallet with the correct force to eliminate waste, and sliding bevel setting need expertise when marking the dovetail joint. It should be noted that furniture construction is a practical course, but these findings show that among the teachers of furniture construction in Zamfara and Katsina State, there is a lack of real practicality. This view was in line with Grollmann \& Rauner's observation [17] that more than $60 \%$ of the workers teaching furniture craft technology in technical colleges were unable to execute the skills or provide technical services that they were required to teach others despite their highlevel paper qualifications. Of course, this is due to the lack of improved skills or the development of non-skills from their respective institutions. Therefore, without sufficient, skilled, and trained furniture craft instructors, modern tools and equipment, as well as facilities to enable our country to achieve economic and technological advancement, the production of furniture craft in Nigerian technical colleges can not be achieved. But with prevailing furniture craft trade issues, its dependency as a foundation for the development of nations can not be a fact unless rapid measures are taken to forestall it. Olumese [18] also pointed out that teaching is a learning facilitation process. Therefore, it is deemed very necessary that prospective teachers should engage with the prevalent teaching atmosphere for successful teaching of furniture craft technology to take place. This 
is because we can not overemphasize the value of teaching furniture craft in our technical colleges, given the country's unemployment rate and the job opportunities provided by the furniture craft trade. This suggests that in Nigerian technical colleges, furniture craft can also provide a better basis for the growth of education and skills for both teachers and students.

Maintenance results include expertise in the repair of the broken band saw blade, sharpening of cross-cut saw teeth, and replacement or reconditioning of worn-out instruments. The consequence of these results is that furniture design teachers need skills to sharpen cross-cut saw teeth, repair, and retrofit worn-out equipment. This was supported Baylor[19] who claimed that knowing the right and modern instruments would provide the furniture craftsman with the good feeling of 'having done it yourself.' Some instruments can be substituted for other instruments, either as a make-shift solution or as an efficiency problem, but a tool can share key functional attributes with one or more other tools by design. With technological advancements, tools used in the construction of furniture are becoming more sophisticated and allow for simple and accurate furniture construction operations. To be able to satisfy the demand for their jobs, furniture design teachers would have to upgrade their skills. Effectively enabling teachers to develop their skills in house training. Skill gap findings show that there are substantial differences between the mean responses of the skills needed and the skills possessed by teachers of technical colleges in Zamfara and Katsina State with low and highly experienced furniture construction. This result was confirmed by Chimpololo[20], who argued that there is a skill deficit in the quality and quantity of technical and skilled skills in the manufacturing industry in Malawi. Furthermore, the findings suggested that the industry lacks multi-skilled technicians capable of performing various functions within their specialist areas [20].

Mullin [21] also stated that skill gaps existed in the skills and knowledge areas gained by graduates completing Higher Education Construction Management programs who are matched with those skills and knowledge areas that industry recognizes as their priority and how capable fresh graduates are at work. The value of rebalancing the teaching of furniture construction between core expertise and "softer" skills needs to be recognized. The gaps found are then necessary for furniture design teachers to fill. On the results of the hypotheses tested, it was found that the mean ratings of the required skills and skills possessed by low experience and high experience in furniture construction teacher had substantial differences. The results showed small differences between teachers with low experience and high experience, which indicates that experience did not influence teachers with highly experienced skills. There is evidence that teachers with both low and high levels of experience obtained instruction during their school days.

\section{CONCLUSION}

It is concluded from this study that furniture construction at Technical Colleges in Zamfara and Katsina State does not, as planned, provide the requisite practical skills in furniture construction. The data collected from this research work has shown that there is a large gap in the skills of teachers with low and high experience. This demonstrates the lack of instructional skills of furniture design teachers in realistic behavior for their 
students. Perhaps the reason why technical college graduates in the furniture industry do not have skills for self-reliance or jobs. The mere acquisition of knowledge-based education in technical colleges needs to be de-emphasized. Teachers with both low and high experience had low qualifications but can be developed by in-house training. Therefore, for technical college graduates to be well educated in furniture construction skills, their instructors must have the required enhancement skills to teach the subject at the college level so that their products can be employed or self-reliant in furniture construction.

Furniture craft teachers in Nigeria should be subject to a set of retraining programs for the construction of furniture. Both through the workplace or in-house training, this could be done. The defined skills needed by furniture construction teachers should form the basis for the inhouse training to be organized as up-skilling workshop training. Emphasize practical tests in the curriculum for furniture construction teachers to instill the value of practical exercise for skill development in the learners. Furniture construction teachers should seek additional training in modern furniture construction technology to benefit from modern furniture construction expertise. Furniture construction teachers should work with industries to acquire knowledge of fundamental skills for furniture industry jobs.

\section{REFERENCES}

[1] P. C. Hussaini, "Multi-Paradigmatic Research Design Spaces for Cultural Studies Researchers Embodying Postcolonial Theorizing," Cult. Stud. Sci. Educ., vol. 4, no. 3, pp. 881-889, 2015.

[2] Nigerian Educational Research and
Development Council (NERDC), National Policy on Education. The Federal Republic of Nigeria, 2014.

[3] D. R. Emma, International Human Resource Management: Policies and Practices for Multi-National Enterprises. New York: Routledge, 2011.

[4] W. Orebanjo and R. Hirschheim, “A Paradigmatic and Methodological Examination of Information Systems Research from 1991 to 2001," Inf. Syst. J., vol. 14, pp. 197-235, 2010.

[5] H. Ede and F. Yusuf, "The Future of Technical and Vocational Education and Training: Global Challenges and Possibilities," Int. J. Adv. Res., vol. 9, no. $1-2$, pp. $2-15,2013$.

[6] A. Rufai, M. Abdulkadir, and A. B. Kagara, "Technical Vocational Education (TVE) Institutions and Industries Partnership: Necessity for Graduates Skills Acquisition," Int. J. Sci. Res. Publ., vol. 3, no. 4, pp. 5461, 2013.

[7] A. Ideh, "The Role of Education for Rural Population Transformation in Bangladesh," Asia-Pacific J. Coop. Educ., vol. 8, no. 1, pp. 1-21, 2013.

[8] A. T. Zubairu, "Actualization of technical vocational education management in Nigeria by 2020: Not a Mirage," J. Sci. Manag., vol. 1, no. 1, pp. 53-62, 2014.

[9] O. Ibrahim, Expanding Employment Capacity. Lagos: Nigerian Graduate Advancement Publication, 2015.

[10] G. Spoettl and V. Tūtlys, "Education and Training for the Fourth Industrial Revolution," J. Pendidik. Teknol. dan Kejuru., vol. 26, no. 1, 2020.

[11] R. Abdulrahman and O. R. Janet, "Expatriate 'Expert' in Indonesia and Thailand professional and personal qualities for Effective Teaching and Consulting," J. Int. Rev. Educ., vol. 37, no. 4, pp. 453-472, 2014.

[12] E. E. Ezewu, "Towards A Taxonomy of Educational Objectives in PsychoProductive Domain," Niger. J. Tech. 
Educ., vol. 2, no. 1, pp. 56-60, 2003.

[13] National Board of Technical Education, Revised Curriculum for Technical Colleges and Polytechnics. Kaduna: National Board for Technical Education, 2003.

[14] U. A. Egbita, "Strategies for Enhancing School to Work Transition of Electrical Electronics Graduate of Polytechnics in Kogi and Nasarawa States," University of Nigeria, 2006.

[15] O. M. Okoro, Principles and Methods in Vocational and Technical. Nsukka: University Trust Publishers, 2008.

[16] D. K. Bukar, Classroom Teaching Skills. New York: McGraw Hill Companies, 2014.

[17] P. Grollmann and F. Rauner, International Perspectives on Teachers and Trainers in Technical and Vocational Education. Dordrecht: Springer, 2007.
[18] H. A. Olumese, "Vocational and Technical Education in Nigeria: Issues, Prospects, and Problems," $J$. Curric. Organ. Niger., vol. 2, no. 1, pp. 11-16, 2004.

[19] C. Baylor, "Furniture Craft Tools Power Tools, Hand Tool and Furniture Craft Machinery," from http://www.answer.com/topi/technolo gy, 2014.

[20] A. Chimpololo, "An Analysis of the Technical and Vocational Skills Gaps in the Manufacturing Industry in Malawi," Int. J. Vocat. Tech. Educ., vol. 9, no. 2, pp. 9-19, 2017.

[21] P. Mullin, "Using Skills Gap Analysis in Construction Management to Stimulate a Demand led Model of Curriculum," IOSR J. Res. Method Educ., vol. 43, no. 5, pp. 45-51, 2014. 